\title{
Analysing The Feature of Meteorological Drought in North East Ethiopia: The Case of Meket and Wadla Districts in North Wello Zone, Amhara Region
}

Mesfin Anteneh ( $\square$ mesfin74@yahoo.com )

National Meteorological Agency

Research

Keywords: North Wello, Drought, Drought Index Calculator, Mann-Kendall, Standardized Precipitation Index (SPI)

Posted Date: November 12th, 2021

DOI: https://doi.org/10.21203/rs.3.rs-1039142/v1

License: (c) (i) This work is licensed under a Creative Commons Attribution 4.0 International License. Read Full License 


\section{Abstract}

The study was undertaken to investigate the magnitude, frequency and trends of drought incidence in North Wello Zone, northeast Ethiopia using monthly rainfall record for the period 1987 to 2017 of Meket and Wadla station. Standard precipitation index and Mann-Kendal test were used to analyse drought event and trends of drought occurrences, respectively. Drought Index Calculator used to analyse standard precipitation index. The coefficient variation of the study area for Meket was (21.2\%), while for Wadla it was (53\%) which showed high inter-annual variability. It was established that both studied stations experienced drought episodes in 1987, 1988, 1991, 1992, 1994, 1998, 1999, 2001, 2006, 2014 and 2015, drought years in the history of Ethiopia. The year 2006 was the most severe and distinct-wide extreme drought episode in both studied stations which standard precipitation index values -2.14 at Wadla and-2.01 at Meket station. The frequency of drought number of years which experienced negative standardize precipitation index values in the total time series of 30 years observed for all time scale at both station is 50 percent and above. The drought magnitude of different time scale varied from slight to extreme severe in the studied stations. The Mann-Kendal trend test shows except two-month timescale at Wadla station, all timescales were not statistically significant $(P<0.05)$. Generally increasing tendencies of drought were observed during main rainy season and decreasing tendencies of drought during short rainy season and annual scale observed in the study area.

\section{Introduction}

Drought is a commonly used term, but the most complex and least realized of all the natural hazards affecting more people than any other hazards (Ashraf \& Routray, 2013). Drought generally characterises as a short term meteorological occurrence, which stems from a shortage of rainfall for a long period of time comparing with its average and normal conditions(Alamgir et al., 2015). Furthermore, (Wilhite, 2000b) described drought as a normal, recurring phenomenon of climate that practically occur in all regions of the world.

There are four types of drought namely; meteorological, agricultural, hydrological and socio-economic droughts(Mishra \& Singh, 2010; Tallaksen et al., 2004). Meteorological drought is deficiency of rainfall which can be observed immediately(PANU \& SHARMA, 2002). Agricultural drought is measured in terms of deficiency in soil moisture, rainfall, ground water and reduction in crop yield (PANU \& SHARMA, 2002; Wilhite, 2000a). Hydrological drought on the other hand is deficiency in water availability in surface and subsurface water reservoirs. Socio-economic drought is final phase of drought that is caused by prolong shortage in agricultural production and food thus affecting overall economy. Recently, (Mishra \& Singh, 2010) suggested adding groundwater drought as a fifth category. Droughts, which originate from deficiency in precipitation over extended periods of time and affect approximately 60 per cent of the world's population, are the major constraints to viable rain-fed agriculture particularly in the ASALs (Huho \& Mugalavai, 2010).The available estimates on drought impacts suggest that, during the period 1998-2017 following the flood, which affected a further 1.5 billion resulting in a huge toll to humanity, killing about 21,563 people(Bettin \& Zazzaro, 2018). For the purpose of this study, meteorological drought was adopted where rainfall is commonly used for drought analysis.

Meteorological Drought is based on the degree of dryness or rainfall deficit and the length of the dry period (Kogan et al., 2019). Most often think about drought in relation to precipitation, assessing the degree of dryness (in comparison to a local or regional average) and the duration of the dry period. This is known as a meteorological drought, which is highly specific to a region as average precipitation may vary considerably spatially. According to (Swain et al., 2017) Meteorological drought occurs when there is a prolonged time with less than average precipitation.

The magnitude and severity of meteorological drought that impacts on social and economic systems of any particular human society will be dependent on the underlying vulnerability and particular region exposed to the event, as well as climate and weather patterns that determine the frequency and severity of the event (Wilhite et al., 2007). In North Wello, prolonged and recurrent drought is the most typical corrupted events of climate change. Remarkably, drought cycle has been shortened than earlier that increases its risk (Oxfam, 2011). As a result, reproductive performance of livestock was reduced despite the fact that livestock mortality is increasing (Dias et al., 2016; Herrero et al., 2010) In North Wello, drought occurs every 1-2 years, compared to every 6-8 years in the past (Mohammed et al., 2018). This threat livestock production system which recurrently erodes the livestock asset before full recovery achieved (Abate \& Angassa, 2016).

Over the past decades and recently there is quite a lot of studies with regard to drought which have been carried out in different parts of drought prone areas and in the study areas such as (Mengistu, 2015; Mwadalu \& Mwangi, 2013; Opiyo et al., 2014). Most of these studies have been devoted to analyze the pastorals and agro pastorals coping strategies towards impacts of the droughts. Moreover, (Mengistu, 2016), studied the Impacts of Drought and Conventional Coping Strategies in Yabello and Dirre districts of Borana Community, Ethiopia, which the survey results show that drought has severely affecting the livestock resource basis of the pastoralists. (Opiyo et al., 2014) also studied on socio economic impact of drought, their coping strategies and government intervention in Marsabit County, Kenya and the results show that water resources, livestock market infrastructure and provision of human health services are affected by drought thus government intervention is needed. Though studies made so far are important they lack the important ingredients which are the extent of the problem by employing different indices including Standard Precipitation Index (SPI), Mann-Kendall's test for rainfall trend analysis (MK) and Coefficient of variation (CV)

\section{Methodology}


The study was conducted in Meket and Wadla districts of North Wello zone in Amhara regional state. North Wello zone is located in southern Ethiopia between $11^{\circ} 20 \mathrm{~N}^{\prime}-11^{\circ} 50^{\prime} \mathrm{N}$ and $38^{\circ} 40^{\prime}-39^{\circ} 30^{\prime} \mathrm{E}$, at a distance of 580 kilometers away from Addis Ababa, the capital of Ethiopia. The study area experiences a bi-modal monsoon rainfall type, where $40 \%$ of the $300-900 \mathrm{~mm}$ annual rainfall occurs during September to October (Belg) and 60\% between June to August (Kiremt) (Gissila et al., 2004). The same source further contends that the average annual temperature of the area is $26.5^{\circ} \mathrm{C}$. The principal feature of rainfall in most parts of North Wollo Zone is its seasonal character, poor distribution and variability from year to year. For the past decades, an erratic distribution of rainfall has been the major climatic factor affecting crop yields in the study area. Subsistence mixed (crop and animal) agriculture is the major means of livelihood in the area with an average farm size of about one hectare (ha). The common growing crops are maize (Zea mays L.), teff (Ergarostis teff Zucc), rice (Oryza galberrima) and beans (Phaseolus vulgaris L.). Other less important crops include chickpea (Cicer arietinum), onion (Allium cepa), cabbage (Brassia aleracea) and Chilie pepper (Capsicum spp.). Various types of crops such as, garlic (Alliium sativum), Ethiopian mustard (Brassica carrinata), oats (Avena sativa) and carrot (Dancus carota sativus) are also cultivated as cash crops. Domestic animals such as cattle, goat, donkey, chicken and bees are kept on traditional basis.

\section{Research Design, Data Sources and Methods of Analysis}

The study was used mixed method, particularly the concurrent triangulation approach as research design. The purpose of mixed methods research is to build on the synergy and strength that exists between quantitative and qualitative research methods to understand a phenomenon more fully than is possible using either quantitative or qualitative methods alone (Gay et al., 2012).

Monthly rainfall data from two stations for the period (1987-2017) were obtained from Ethiopian National Meteorological Agency (NMA) and used as an input variable to calculate meteorological drought. To fill the missing values, data were generated following the first order Markov chain model using INSTAT plus (v3. 6) Software ((Roger Stern, Derk Rijks, lan Dale, 2006).

Drought Index Calculator (DrinC) which was developed by the Laboratory of Reclamation Works and Water Resources Management, National Technical University of Athens was used to analyze (SPI) standard precipitation index (Tigkas et al., 2015)

\section{Standard Precipitation Index Computation}

SPI is used to identify the meteorological drought or deficit of precipitation for multiple timescales in the studied stations (Mckee et al., 1993). The $\mathrm{SPI}$ is a z-score and represents the drought event departure from the mean, expressed in standard deviation units. Although SPI can be calculated from 1 month up to 72 months, 1-24 months is the best practical range of application (Guttman, 1999; World Meteorological Organization, 2012). The SPI values were computed at three time-scales, as used (Mohammed et al., 2018) 2 months (SPI-2), 3 months (SPI-3) and 12 months or annual (SPI-12). The SPI-2 was used to assess drought during Belg season, SPI-3 was used to assess droughts during Kiremt seasons, which represent the shorter and main rainy seasons, respectively, and SPI-12 was used to assess the annual drought.

A drought occurs when the SPI is consecutively negative and its value reaches an intensity of -1 or less and ends when the SPI becomes positive. For each month of the calendar year, new data series were created, with the elements equal to corresponding rainfall moving sums (Degefu \& Bewket, 2015). Then, the SPI value provides a comparison of the rainfall over a specific period with the rainfall totals from the same period for all the years included in the historical record (Mohammed et al., 2018; Shahid, 2008).To calculate the SPI, a long-term precipitation record at the desired station is first fitted to a probability distribution (e.g. gamma distribution), which is then transformed into a normal distribution so that the mean SPI is zero (Edwards, 1997; Mckee et al., 1993). It is expressed mathematically as follows:

$S P I_{\mathrm{ij}}=\frac{\mathrm{Xij}-\mu \mathrm{ij}}{\delta \mathrm{ij}}$

Where $\mathrm{SPI}_{\mathrm{ij}}$ is the SPI of the $\mathrm{i}^{\text {th }}$ month at the $\mathrm{j}^{\text {th }}$ timescale, $\mathrm{X}_{\mathrm{ij}}$ is rainfall total for the $\mathrm{i}^{\text {th }}$ month at the $\mathrm{j}^{\text {th }}$ time $s c a l e, \mu_{\mathrm{ij}}$ and $\mathrm{a}_{\mathrm{ij}}$ are the long-term mean and standard deviation associated with the $\mathrm{i}^{\text {th }}$ month at the $\mathrm{j}^{\text {th }}$ time scale, respectively. Drought Index Calculator (DrinC) which was developed by the Laboratory of Reclamation Works and Water Resources Management, National Technical University of Athens used to analyze standard precipitation index (SPI) (Tigkas et al., 2015)

(McKee et al., 1993) first defined the index and the criteria for drought classifications by SPI values. In this research, the modified classification of (Alamgir et al., 2015) as shown in Table 1. 
Table 1

SPI based drought severity class

\begin{tabular}{|llll|}
\hline Index Value & Class SPI & Value & Drought severity class \\
\hline $\mathrm{SPI} \geq 2.0$ & Extremely wet & & \\
$1.5 \leq \mathrm{SPI}<2.0$ & Very wet & Above 0 & No drought \\
\hline $1.0 \leq \mathrm{SPI} \leq 1.5$ & Moderately wet & & \\
\hline$-1.0<\mathrm{SPI}<1.0$ & Nearly Normal & 0.0 to -0.99 & Slight drought \\
\hline$-1.5<\mathrm{SPI} \leq-1.0$ & Moderate dry & -1.0 to -1.49 & Moderate drought \\
$-2.0<\mathrm{SPI} \leq-1.5$ & Severely dry & -1.5 to -1.99 & Severe drought \\
\hline SPI $\leq-2.0$ & Extremely dry & -2 and less & Extreme drought \\
\hline Source: Adapted from (Alamgir et al., 2015) & \\
\hline
\end{tabular}

\section{Trend Detection and Analysis}

The study was employed Mann-Kendall's test for rainfall trend analysis. Mann-Kendall's test checks the hypothesis of no trend versus the alternative hypothesis of the being increasing or decreasing trend (Collins, 2009). The study of (Yue et al., 2002) and (Viste et al., 2013) noted that these tests have to identify trends in time series.

\section{$\mathrm{S}=\sum_{i-1}^{N-1} \sum_{J=l+1}^{N} \operatorname{sgn}(\mathrm{xj}-\mathrm{xi})$}

Where $S$ is the Mann-Kendal's test statistics; $x i$ and $x j$ are the sequential data values of the time series in the years $i$ and $j(j>i)$ and $N$ is the length of the time series.

$\operatorname{Sign}(x j-x i)=\left\{\begin{array}{c}+1, \text { if }(x j-x i)>0 \\ 0, \text { if }(x j-x i)=0 \\ -1 \text { if }(x j-x i)<0\end{array}\right\}$

The variance of $S$, for the situation where there may be ties (that is equal values) in the $x$ values, is given by:

$\operatorname{Var}(S)=\frac{1}{18}\left[N(N-1)(2 N+5)-\sum_{i=1}^{M} t\left(\left(t_{i}-1\right)\left(2 t_{i}+5\right)\right)\right]$

Where, $m$ is the number of tied groups in the data set and $t i$ is the number of data points in the ith tied group. For $\mathrm{n}$ larger than 10 , ZMK approximates the standard normal distribution (Partal \& Kahya, 2006; Yenigün et al., 2008) and computed as follows:

$\mathrm{Z}_{\mathrm{MK}}=\left\{\begin{array}{cc}\frac{s-1}{\sqrt{\operatorname{Var}}(s)} & \text { if } S>0 \\ 0 & \text { if } S=0 \\ \frac{s+1}{\sqrt{\operatorname{Var}(s)}} & \text { if } S<0\end{array}\right.$

The presence of a statistically significant trend is evaluated using the $Z_{M K}$ value. In a two-sided test for trend, the null hypothesis Ho should be accepted if at a given level of significance. $\mathrm{Z} 1-\alpha / 2$ is the critical value of $\mathrm{Z}_{\mathrm{MK}}$ from the standard normal table. For example, for $5 \%$ significance level, the value of $\mathrm{Z} 1-\mathrm{a} / 2$ is 1.96 .

MK test, used by many researchers for trend detection due to its robustness for non-normally distributed data, was applied in this study to assess trends in the time series data (Kendall, 1957). The significance level of the slope was estimated using Sen's method. Sen's slope (Q) estimates methods account for seasonality of the precipitation data. This method uses a simple non-parametric procedure developed by sen's (1968) to estimate the slope. The nonparametric tests are used to detect trends but don't quantify the size of the trend or change. Hence, magnitude of the observed trend can be estimated with sen's slope estimator when significant (Paulo et al., 2012).

\section{Coefficient of variation}

The rainfall variability for Meket and Wadla meteorological stations was calculated using the Coefficient of variation (CV) to evaluate the interannual variability of seasonal and annual rainfall is computed as: 
$C V=\frac{\delta}{\dot{x}}$

Where $\mathrm{CV}=$ Coefficient of Variations

$\delta=$ Standard Deviation

$\dot{\mathrm{x}}=$ Mean

$\mathrm{CV}<20 \%$ indicate low variability, CV between $20 \%$ and $30 \%$ indicate moderate rainfall variability, CV $>30 \%$ indicate high, CV $>40 \%$ very high and CV $>70 \%$ indicate extremely high inter-annual variability of rainfall as used by(Girma et al., 2016; Hadgu et al., 2013; Zegeye, 2018)

\section{Result And Discussion}

\section{Magnitude and frequencies of drought}

The number of drought months with different magnitude classes at short and long timescales (2, 3 and 12-months) is shown on different Figures. Drought months for 2 months (Short rainy season), 3 months (main rainy season) and 12 months (annual rainfall) were calculated using SPI. Drought frequency, in this study, was measured by the number of years which experienced negative SPI values in the total time series of 30 years.

Main rainy season (Kiremt): The total number of drought events with slight, moderate, severe and extreme severe computed at three-month timescale (June-August) was accounted for 50 per cent in main rainfall season in Meket stations and $53.3 \%$ per cent in Wadla station, Figures 1 and 2. However, they had varied magnitude classes. Severe drought was recorded in 1999, 2000, 2008 and 2011 in Meket station which ranges from -0.15 to -1.53 where severe drought was recorded in Wadla station in 1996 and 1992 which ranges from -1.59 to - 1.85 . Extreme severe drought was recorded in the year 2006 only in Meket stations with SPI value - 2.11, which had substantial impact on the area whereas in Wadla station extreme severe drought wasn't recorded in the studied year, Figure 2.

The analysis of three-month timescale (June-August) showed, the year 1988, 1991, 1992, 1998, 2001, 2008, 2014, 2015, and 2016 were drought years in both studied stations. Generally, the drought magnitude of three months timescale varied from slight to extreme severe in the studied stations. The main rainy season in Meket station shows decreasing which means the tendencies of drought is increasing while in Wadla station the main rainy season is increasing which shows drought is decreasing. The main source of water for the study areas is rainfall, so any change in rainfall amount and distribution lead to serious production deficit and undermining the delicate balance between pasture and livestock as well as crop growth and moisture availability on which mixed subsistence farming livelihood depends (Hagosa et al., 2011). Main rainy season (June, July, August) rainfall contributed the highest Percentages $52.2 \%$ and $48.3 \%$ of rainfall to annual rainfall at Meket and Wadla respectively. So, failure of this season made subsistence farmers vulnerably to the drought impacts.

Short rainy season (Belg): The total number of drought events at the two-month timescale (September and October) in the entire period of analysis was found between 16 months at Meket and 15 months at Wadla station respectively, Figures 3 and 4 . Meket had extreme severe drought with SPI value -2.28 at this timescale in 2015 drought year. Severe drought was occurred in 1993, 2002 and 2006 which values ranges from -1.55 to -1.76 at Wadla station, whereas in Meket station severe drought occurred in 1992 with SPI values of -1.68.

Even though its magnitude varied, drought occurred across the study area at this timescale in 1997, 1998, 2002, 2003, 2006, 2015 and 2016. The frequency of occurrences of drought at this season was the highest at Meket, implying that Meket experienced one drought episode in almost every two to three years. Generally, the drought magnitude of two-month timescale varied from slight to Extreme severe in the studied stations. Short rainy season (February and March) also contribute $21.4 \%$ and 24.7\% at Meket and Wadla station, respectively. However, in Meket the SPI result shows drought is being constant which means not varying while in Wadla station the tendencies of short season drought is decreasing.

Annual drought: The total number of drought year at 12month timescale (January-December) was found 15 at Meket and 16 at Wadla which constitutes 50 and 53.3 per cent of the total number of drought incidences in the study period, respectively, Figures 5 and 6 . At this time scale, the highest severe drought was recorded at Meket in 2006 and 1999 with SPI value of -2.01 and -2.04, respectively, whereas, in Wadla station extreme severe drought was recorded in 2006 with SPI value of -2.14 . This implies in 2006 both areas were undergone extreme severe drought events which had large effects on the smallholder farmers. This is supported by other study (Deressa et al., 2009; Mera, 2018)who stated in their study that 7.4 million people affected; 247,000 livestock died in Borana lowlands, Tigray, Amhara, Afar and Somali Regions in 2006 drought.

The analysis of 12 month timescale drought was recorded across the study areas in $1987,1988,1991,1992,1994,1998,1999,2001,2006,2014$ and 2015 although there was varying by degree of severity. The total number of moderate droughts at $12 \mathrm{month}$ timescale was the 13 months at Wadla and 9 months at Meket. This study confirms that the frequency of occurrences of droughts in the main rainy season was the highest at Wadla station. Generally, the rainfall pattern in the studied stations exhibits certain characteristics that a drought year are followed by another two or three dry years vis-à-vis the wet years. This study is in line with the findings of (Girma et al., 2016; Hadgu et al.,2013)

Page 5/13 
Trends of drought occurrences for 2 months (Short rainy season), 3 months (Main rainy season) and 12 months (annual) timescales were shown in Figures 7 and 8. SPI values of January, February and March were considered to represent the drought conditions from June, July and August (Main rainy season), September to October (Short rainy season) and January-December (annual rainfall), respectively.

The computed SPI values for 3 months timescale during main rainfall season revealed that the occurrence of negative rainfall anomalies or frequent droughts were observed in the 1990s and 2000s in Wadla station while in Meket station frequent droughts were observed in 2010s. The main rainfall season trend for 3 months timescale shows decreasing in Meket and increasing in Wadla station (Figure7\& 8). The short rainfall season for 2 months timescale in Wadla station showed increasing trends, which indicates declining of occurrences of droughts from time to time across the study stations while the Meket station showed decreasing trends which implies increasing the occurrences of droughts in the area. The computed SPI value for 12 months (annual) timescale showed increasing trend at both studied station. This implies decreasing of incidences of drought at 12 months (annually).

MK (Mann Kendall) test used by many researchers for trend detection due to its robustness for non-normally distributed data, was applied in this study to assess trends in the time series data (Kendall, 1957).

The MK(Mann Kendall) trend test showed decreasing changes in SPI values in Meket stations, which implies increasing the tendency of drought incidences at main rainy season, while Wadla station showed increasing trend that implies declining of the tendency of drought incidences (Table 2.) On the other hand, SPI values at the 2 month timescale during short rainy season showed increasing changes at both stations, similar increasing trend of drought was also observed at 12-month timescale in both stations. The trend analysis shows except at the two-month time scale in Wadla station there was no statistical significance $(p<0.05)$ of any positive or negative trend of meteorological drought severity and frequency for both stations. Generally, detection of trends using nonparametric methods, including Sen's method and the Mann-Kendall test, showed increasing tendencies of drought during main rainy season and decreasing tendencies of drought during short rainy season and annual scale in the study region.

Table 2

SPI MK trends for Meket and Wadla station

\begin{tabular}{|llll|}
\hline Stations & SPI- 2 months & SPI-3 months & SPI- 12 months \\
\cline { 2 - 4 } & $\begin{array}{l}\text { Trend P-value Sen } \\
\text { Slope }\end{array}$ & Trend P-value Sen's slope & Trend P-value Sen's slope \\
\hline Meket & 0.050 .980 .008 & $-0.100 .4-0.02$ & \\
Wadla & $0.28^{*} 0.030 .048$ & 0.120 .320 .03 & 0.010 .940 .002 \\
*=significant at $\mathrm{p}<0.05$ & & 0.230 .070 .04 \\
\hline
\end{tabular}

\section{Rainfall variability}

The coefficient of variation of the seasonal and annual rainfall of the stations is presented in Table 3 indicated that rainfall variability at Meket $\mathrm{CV}=21.2 \%$ while, Wadla station has $\mathrm{CV}=53 \%$. The region has moderate and very high Rainfall variability respectively. Main rainy season (June, July, August) rainfall contributed the highest Percentages $52.2 \%$ and $48.3 \%$ of rainfall to annual rainfall at Meket and Wadla respectively and short rainy season (September and October) also contribute $21.4 \%$ and $24.7 \%$ at Meket and Wadla station respectively. This result agreed with the findings of (Viste et al., 2013) and (Girma et al., 2016), who reported that main seasons contributed the highest contribution to annual rainfall .

The main rainfall season, coefficient of variation range was $32.6 \%$ at Meket station which shows high variability while $71.2 \%$ at Wadla station which implies very high variability in the study area (Table 3). The analysis of coefficient of variation for short season (September to October) at Meket station was $48.3 \%$ which shows very high variability and $94.4 \%$ at Wadla station which is extremely variable. This shows that variability in both areas is higher than main seasonal rainfall which agreed with many other authors (Girma et al., 2016; Hadgu et al., 2013). The short rainy season rainfall at both stations shows the highest variation of rainfall distribution with the highest coefficient of variation, followed by the main rainy season and annual rainfall respectively. This is consistent with previous studies, (Ayal et al., 2018), that conclude that greater rainfall variability is experienced during the small rainy season than the main rainy season and annual rainfall. General, the study site experiences moderate to extremely high inter annual rainfall variability. 
Table 3

Annual and seasonal rainfall variability for Meket and Wadla Station

\begin{tabular}{|llll|}
\hline \multirow{2}{*}{ Station } & Annual & Main Rainfall Season & Short Rainfall Season \\
\cline { 2 - 5 } & Mean SD CV & Mean SD \% CV & Mean SD \% CV \\
\hline Meket & 597126.9421 .2 & 311.6101 .652 .232 .6 & 12862.1321 .448 .3 \\
Wadla & 514.3272 .753 .0 & 247.2176 .148 .371 .2 & 127.6120 .524 .794 .4 \\
\hline \multicolumn{2}{|l}{ SD standard deviation, CV coefficients of variation } \\
\hline
\end{tabular}

As reported by (Bewket, 2009)and (Tessema \& Simane, 2020) extreme high and low rainfall values within the study period could influence the rainfall trend. So, both seasonal and annual rainfall distribution variability, negatively affect the socio-economic activities of the smallholder farmers that mostly depend on rain fed.

\section{Conclusion}

This study investigated the frequency, magnitude and trends of drought over north Wello during the short and main rainy seasons and the annual period for the period 1987-2017. The study was able to identify the major drought years within the study period with drought severity. The assessment of meteorological drought showed the occurrence of slight to extreme severe in the historical drought episodes in the studied stations.

The meteorological data results revealed greater rainfall variability is experienced during the small rainy season and followed by the main rainy season and lastly annual rainfall at the both station which in turn call for close follow up attention so as to provide timely response to the vulnerable community. Generally, the implication of this study is that drought events and their negative effects are highly localized in the study area and there is a need for local-scale planning for drought management and response. Local climate studies, such as the present study, should be strengthened since they are useful to provide fine scale climate information for drought risk management and adaptation purposes. Moreover, it may contribute decision makers in planning actions for management of drought and reducing the impact of drought/dryness in the area.

\section{Declarations}

\section{ACKNOWLEDGEMENT}

The author would like to thank the National Meteorological Agency and those of Meket and Wadla meteorological stations for the provision of meteorological data and for their cooperation related to the study

\section{Author's contributions}

M A was responsible for all activities of the research process such as the design, data compilation and entry, data analysis, and interpretation of results as well as writing up of the manuscript.

\section{Funding}

This study was financially supported by Bahir Dar University.

\section{Availability of data and materials}

The datasets used and/or analyzed during the current study are available from the corresponding author on reasonable request.

\section{Declarations Competing interests}

The authors declare that they have no conflict of interests

\section{Competing interests}

The authors declare that they have no competing interests

\section{References}

1. Abate T, Angassa A (2016) Conversion of savanna rangelands to bush dominated landscape in Borana, Southern Ethiopia. Ecological Processes. https://doi.org/10.1186/s13717-016-0049-1 
2. Alamgir M, Shahid S, Hazarika MK, Nashrrullah S, Harun S, Bin, Shamsudin S (2015) Analysis of Meteorological Drought Pattern During Different Climatic and Cropping Seasons in Bangladesh. J Am Water Resour Assoc. https://doi.org/10.1111/jawr.12276

3. Ashraf M, Routray JK (2013) Perception and understanding of drought and coping strategies of farming households in north-west Balochistan. International Journal of Disaster Risk Reduction. https://doi.org/10.1016/j.ijdrr.2013.05.002

4. Ayal DY, Radeny M, Desta S, Gebru G (2018) Climate variability, perceptions of pastoralists and their adaptation strategies: Implications for livestock system and diseases in Borana zone. Int J Clim Change Strateg Manag. https://doi.org/10.1108/IJCCSM-06-2017-0143

5. Bettin G, Zazzaro A (2018) The Impact of Natural Disasters on Remittances to Low- and Middle-Income Countries. Journal of Development Studies. https://doi.org/10.1080/00220388.2017.1303672

6. Bewket W (2009) Rainfall variability and crop production in Ethiopia Case study in the Amhara region. Proceedings of the 16th International Conference of Ethiopian Studies, Ed. by Svein Ege, Harald Aspen, Birhanu Teferra and Shiferaw Bekele, Trondheim 2009.

https://doi.org/http://portal.svt.ntnu.no/sites/ices16/Proceedings/Volume\%203/Woldeamlak\%20Bewket\%20-

\%20Rainfall\%20variability\%20and\%20crop\%20production.pdf

7. Chakraborty S, Tiedemann AV, Teng PS (2000) Climate change: Potential impact on plant diseases. Environ Pollut. https://doi.org/10.1016/S0269-7491(99)00210-9

8. Collins MJ (2009) Evidence for changing flood risk in New England since the late 20th century. J Am Water Resour Assoc. https://doi.org/10.1111/j.1752-1688.2008.00277.x

9. Debela N, Mohammed C, Bridle K, Corkrey R, McNeil D (2015) Perception of climate change and its impact by smallholders in pastoral/agropastoral systems of Borana, South Ethiopia. SpringerPlus. https://doi.org/10.1186/s40064-015-1012-9

10. Degefu MA, Bewket W (2015) Trends and spatial patterns of drought incidence in the Omo-Ghibe River Basin, Ethiopia. Geografiska Annaler, Series A: Physical Geography. https://doi.org/10.1111/geoa.12080

11. Deressa TT, Hassan RM, Ringler C, Alemu T, Yesuf M (2009) Determinants of farmers' choice of adaptation methods to climate change in the Nile Basin of Ethiopia. Glob Environ Change. https://doi.org/10.1016/j.gloenvcha.2009.01.002

12. Dias CSL, Rodrigues RG, Ferreira JJ, Jamshidi O, Asadi A, Kalantari K, Azadi H, Scheffran J, Hellin J, Ndjeunga J, Trench P, Pratt T, Allen LN, Rosenberg DE, Keller AA, Kopp K, Abdul-Razak M, Kruse S, Tucker J, Mathijs E (2016) A Status Quo Review of Climate Change and the Agriculture Sector of the Western Cape Province. Ecosystem Services

13. Edwards DC (1997) Characteristics of 20th Century drought in the United States at multiple time scales. AIR FORCE INST OF TECH WRIGHTPATTERSON AFB OH. Atmospheric Science Paper No. 634, May 1-30

14. Gay LR, Mills GE, Airasian P (2012) Competencies for Analysis and Applications 10th Edition. In Pearson Education, Inc

15. Girma E, Tino J, Wayessa G (2016) Rainfall trend and variability analysis in Setema-Gatira area of Jimma, Southwestern Ethiopia. Afr J Agric Res. https://doi.org/10.5897/ajar2015.10160

16. Gissila T, Black E, Grimes DIF, Slingo JM (2004) Seasonal forecasting of the Ethiopian summer rains. Int J Climatol. https://doi.org/10.1002/joc.1078

17. Guttman NB (1999) Accepting the standardized precipitation index: A calculation algorithm. J Am Water Resour Assoc. https://doi.org/10.1111/j.1752-1688.1999.tb03592.x

18. Hadgu G, Tesfaye K, Mamo G, Kassa B (2013) Trend and variability of rainfall in Tigray, Northern Ethiopia : Analysis of meteorological data and farmers ' perception. Academia Journal of Agricultural Research. https://doi.org/10.15413/ajar.2013.0117

19. Hagosa F, Makombe G, Namara R, Awulachew S (2011) Importance of Irrigated Agriculture to the Ethiopian Economy: Capturing the direct net benefits of irrigation. Ethiopian Journal of Development Research. https://doi.org/10.4314/ejdr.v32i1.68597

20. Herrero M, Ringler C, Steeg J, Van De, Koo J, Notenbaert A (2010) Climate variability and climate change and their impacts on Kenya's agricultural sector. ILRI, Nairobi Kenya. https://doi.org/10.5539/jsd.v6n2p9

21. Huho JM, Mugalavai EM (2010) The Effects of Droughts on Food Security in Kenya. The International Journal of Climate Change: Impacts and Responses. https://doi.org/10.18848/1835-7156/cgp/v02i02/37312

22. Kendall MG (1957) Rank Correlation Methods. 4th Edition. In Charles Griffin, London

23. Kogan F, Guo W, Yang W (2019) Drought and food security prediction from NOAA new generation of operational satellites. Geomatics, Natural Hazards and Risk. https://doi.org/10.1080/19475705.2018.1541257

24. McKee TB, Kleis NJD, John (1993) Proceedings of the 8th Conference on Applied Climatology. The Relationship of Drought Frequency and Duration to Time Scales

25. Mckee TBT, Doesken NJNJ, Kleist J, McKee, Doesken NJNJ, Kleist J, Mckee TBT, ., Doesken NJNJ, Kleist J (1993) The relationship of drought frequency and duration to time scales. Eighth Conference on Applied Climatology. American Meteorological Society, Boston. Eighth

Conference on Applied Climatology 
26. Mengistu D (2015) Factors Affecting the Choices of Coping Strategies for Climate Extremes: The Case of Yabello District, Borana Zone, Oromia National Regional State, Ethiopia. Science Research. https://doi.org/10.11648/j.sr.20150304.11

27. Mengistu D (2016) Impacts of Drought and Conventional Coping Strategies of Borana Community, Southern Ethiopia. Research on Humanities and Social Sciences

28. Mera GA (2018) Drought and its impacts in Ethiopia. In Weather and Climate Extremes. https://doi.org/10.1016/j.wace.2018.10.002

29. Mishra AK, Singh VP (2010) A review of drought concepts. J Hydrol. https://doi.org/10.1016/j.jhydrol.2010.07.012

30. Mohammed Y, Yimer F, Tadesse M, Tesfaye K (2018) Meteorological drought assessment in north east highlands of Ethiopia. Int J Clim Change Strateg Manag. https://doi.org/10.1108/IJCCSM-12-2016-0179

31. Mwadalu R, Mwangi M (2013) The potential role of sorghum in enhancing food security in semi-arid eastern Kenya: A review. Journal of Applied Biosciences. https://doi.org/10.4314/jab.v71i1.98826

32. Opiyo FEO, Wasonga OV, Nyangito MM (2014) Measuring household vulnerability to climate-induced stresses in pastoral rangelands of Kenya: Implications for resilience programming. Pastoralism. https://doi.org/10.1186/s13570-014-0010-9

33. Oxfam (2011) Briefing on the Horn of Africa Drought 2011. Management

34. PANU US, SHARMA TC (2002) Challenges in drought research: some perspectives and future directions. Hydrol Sci J. https://doi.org/10.1080/02626660209493019

35. Partal T, Kahya E (2006) Trend analysis in Turkish precipitation data. Hydrol Process. https://doi.org/10.1002/hyp.5993

36. Paulo AA, Rosa RD, Pereira LS (2012) Climate trends and behaviour of drought indices based on precipitation and evapotranspiration in Portugal. Natural Hazards and Earth System Science. https://doi.org/10.5194/nhess-12-1481-2012

37. Roger Stern D, Rijks I, Dale JK (2006) Instant Climatic Guide. January, 1-330. https://www.researchgate.net/profile/Roger_Stern/publication/264879427_Instat_Climatic_Guide/links/566532fb08ae4931cd60a556/InstatClimatic-Guide.pdf

38. Shahid S (2008) Spatial and temporal characteristics of droughts in the western part of Bangladesh. Hydrol Process. https://doi.org/10.1002/hyp.6820

39. Swain S, Patel P, Nandi S (2017) Application of SPI, EDI and PNPI using MSWEP precipitation data over Marathwada, India. International Geoscience and Remote Sensing Symposium (IGARSS). https://doi.org/10.1109/IGARSS.2017.8128250

40. Tallaksen LMLM, Van Lanen HAJ, Van Lanen HAJ, Van Lanen HAJ (2004) Hydrological Drought: Processes and Estimation Methods for Streamflow and Groundwater Developments in Water science. Elsevier

41. Tessema I, Simane B (2020) Smallholder Farmers' perception and adaptation to climate variability and change in Fincha sub-basin of the Upper Blue Nile River Basin of Ethiopia. GeoJournal. https://doi.org/10.1007/s10708-020-10159-7

42. Tigkas D, Vangelis H, Tsakiris G (2015) DrinC: a software for drought analysis based on drought indices. Earth Sci Inf. https://doi.org/10.1007/s12145-014-0178-y

43. Viste E, Korecha D, Sorteberg A (2013) Recent drought and precipitation tendencies in Ethiopia. Theoret Appl Climatol. https://doi.org/10.1007/s00704-012-0746-3

44. Wilhite DA (2000a) Drought as a natural hazard: Concepts and definitions. Drought: A Global Assessment

45. Wilhite DA (2000b) Drought preparedness and response in the context of Sub-Saharan Africa. J Contingencies Crisis Manag. https://doi.org/10.1111/1468-5973.00127

46. Wilhite DA, Svoboda MD, Hayes MJ (2007) Understanding the complex impacts of drought: A key to enhancing drought mitigation and preparedness. Water Resour Manage. https://doi.org/10.1007/s11269-006-9076-5

47. World Meteorological Organization (2012) Standardized Precipitation Index User Guide (M. Svoboda, M. Hayes and D. Wood). WMO-No. 1090 (C)

48. Yenigün K, Gümüş V, Bulut H (2008) Trends in streamflow of the Euphrates basin, Turkey. Proceedings of the Institution of Civil Engineers: Water Management. https://doi.org/10.1680/wama.2008.161.4.189

49. Yue S, Pilon P, Cavadias G (2002) Power of the Mann-Kendall and Spearman's rho tests for detecting monotonic trends in hydrological series. J Hydrol. https://doi.org/10.1016/S0022-1694(01)00594-7

50. Zegeye H (2018) Climate change in Ethiopia: impacts, mitigation and adaptation.International Journal of Researh in Environmental Studies

\section{Figures}




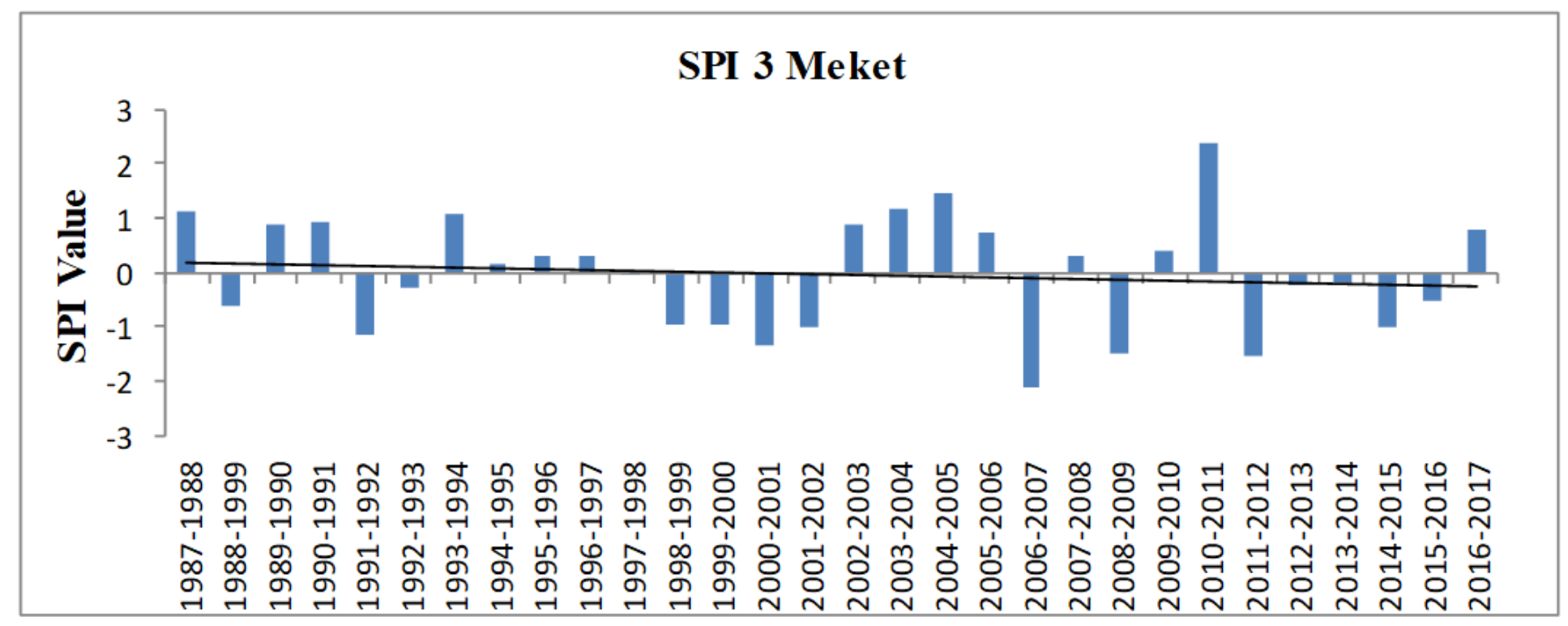

Figure 1

Month timescale of SPI at Meket station

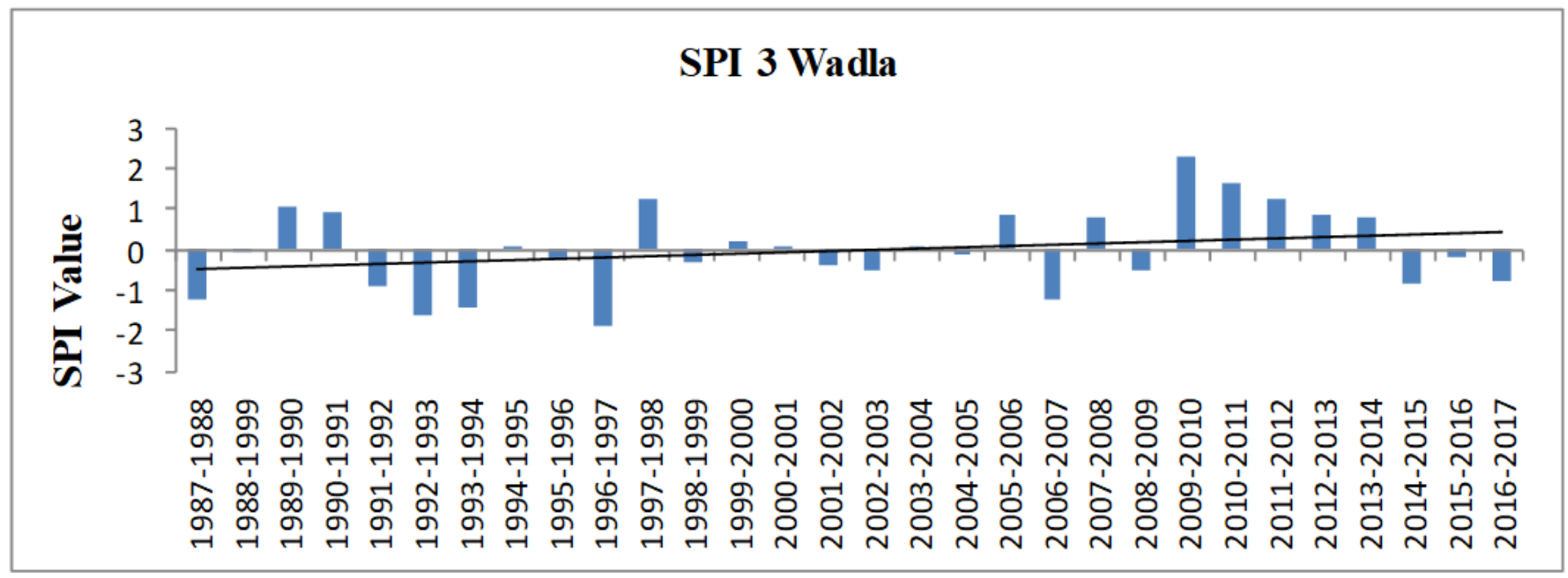

Figure 2

Month timescale SPI at Wadla station 


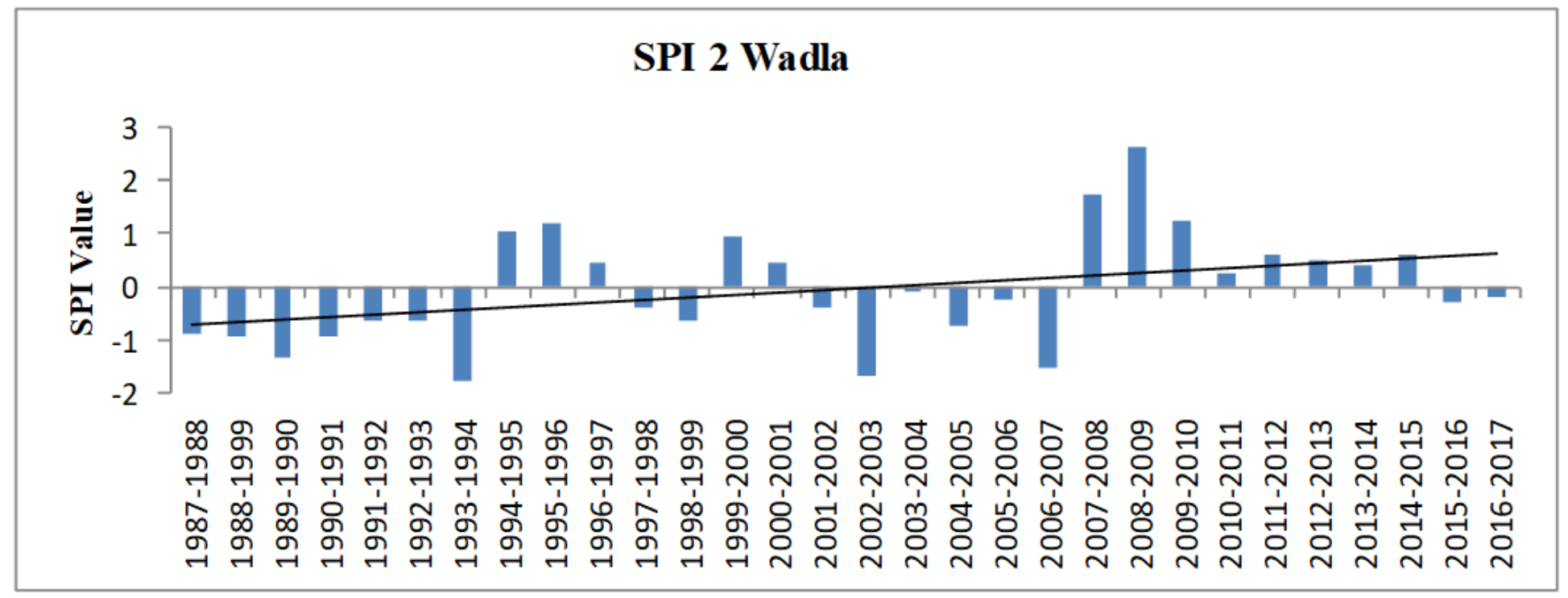

Figure 3

Month timescale SPI at Wadla station

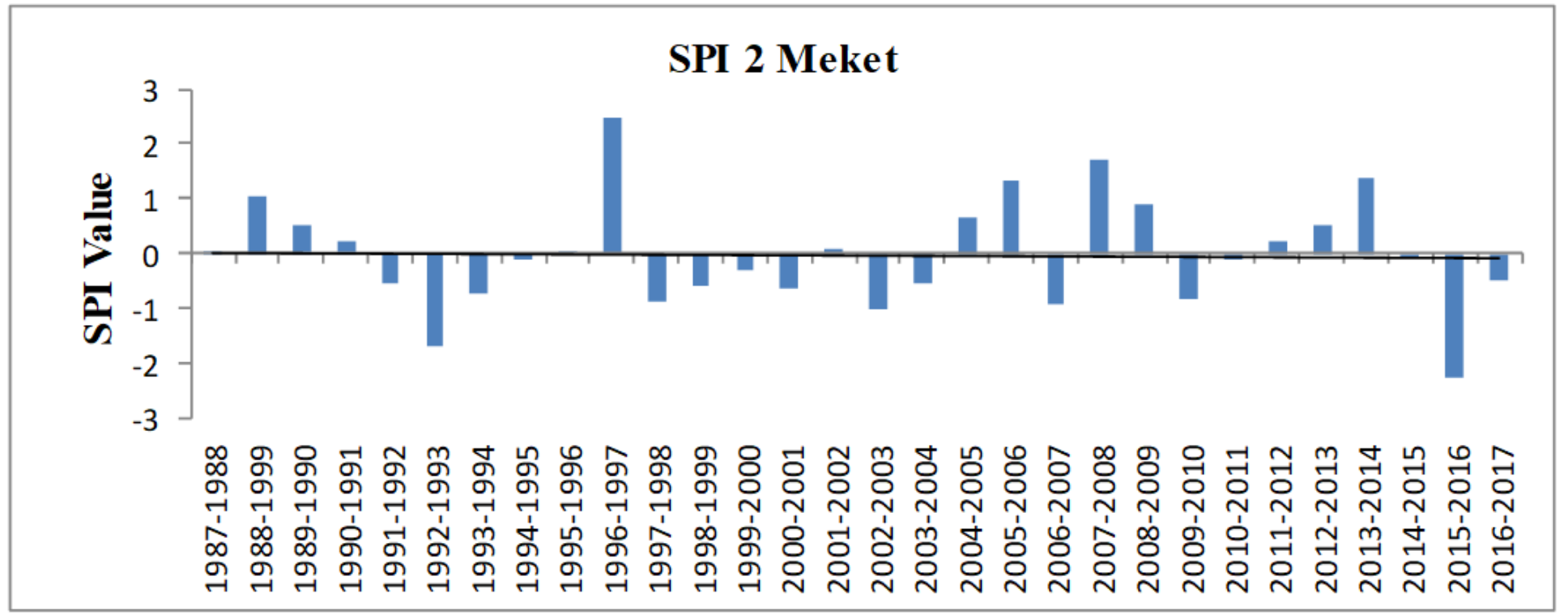

Figure 4

Month timescale SPI at Meket station 


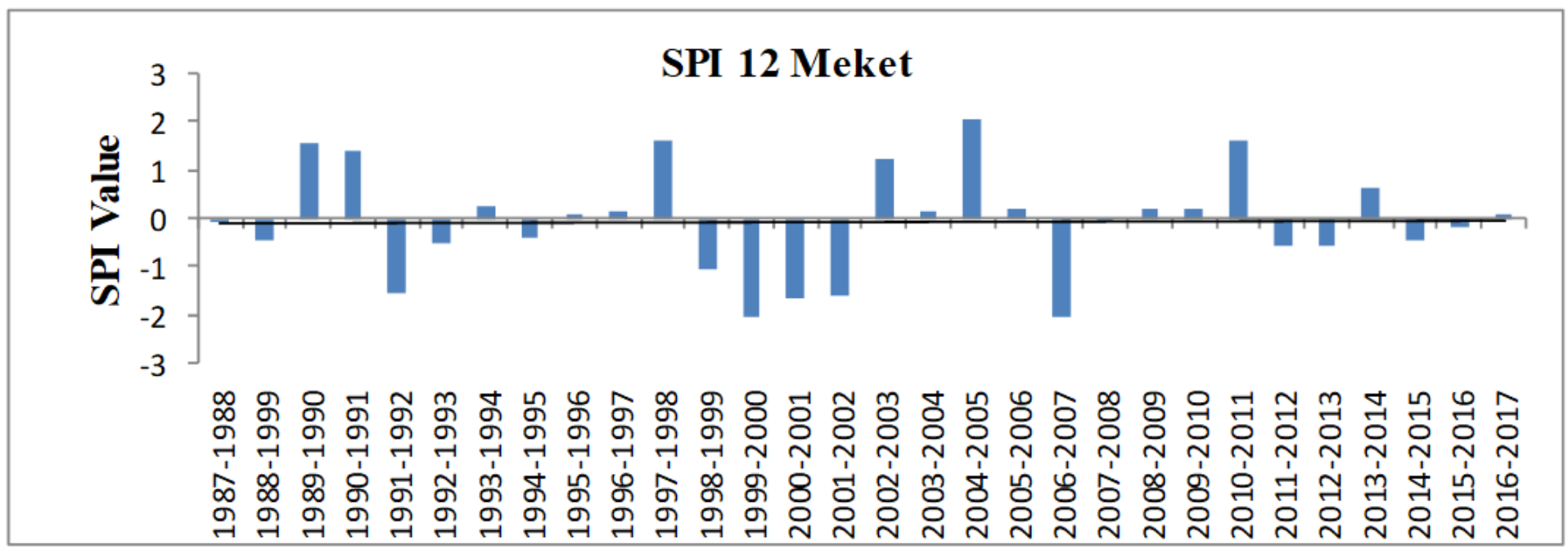

Figure 5

Months (Annual) timescale SPI at Meket station

\section{SPI 12 Wadla}

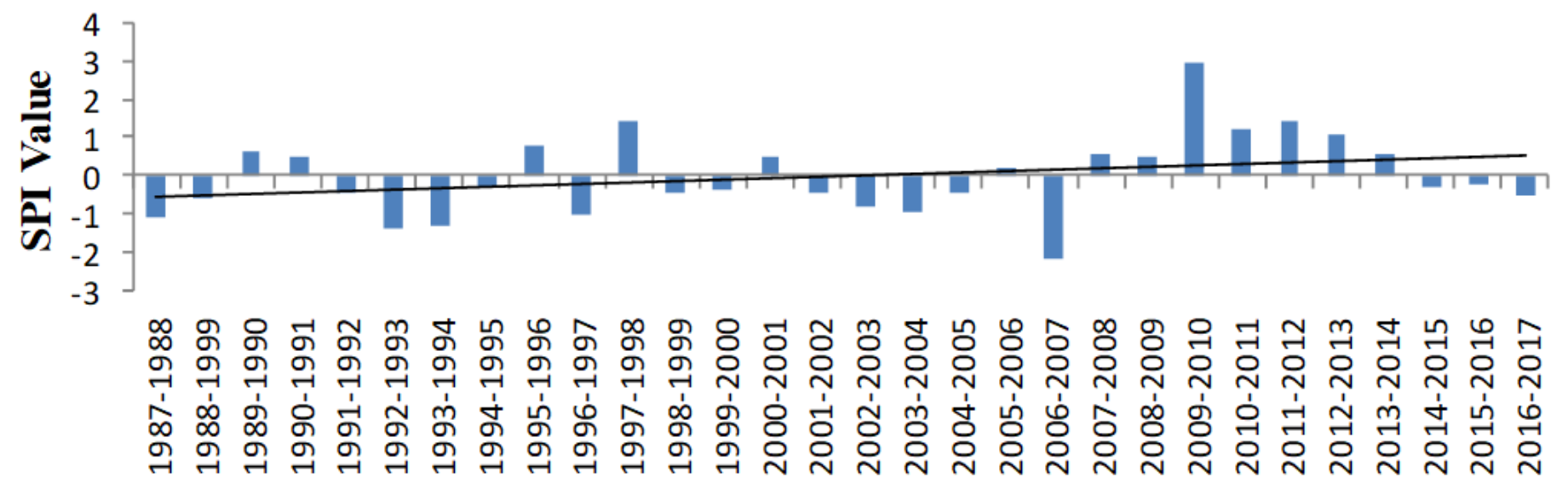

Figure 6

Month timescale SPI at Wadla station 


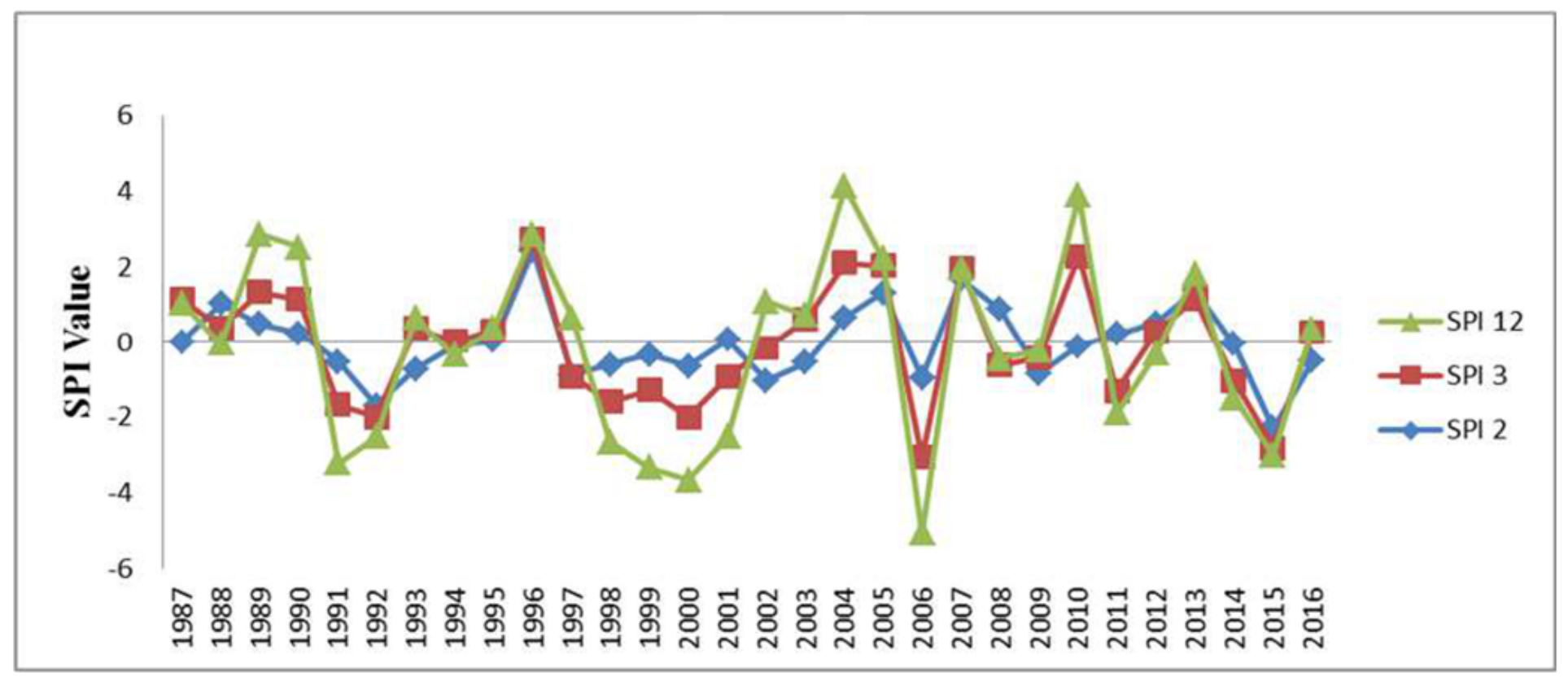

Figure 7

Trends of SPI value (2, 3 and 12 months) at Meket station.

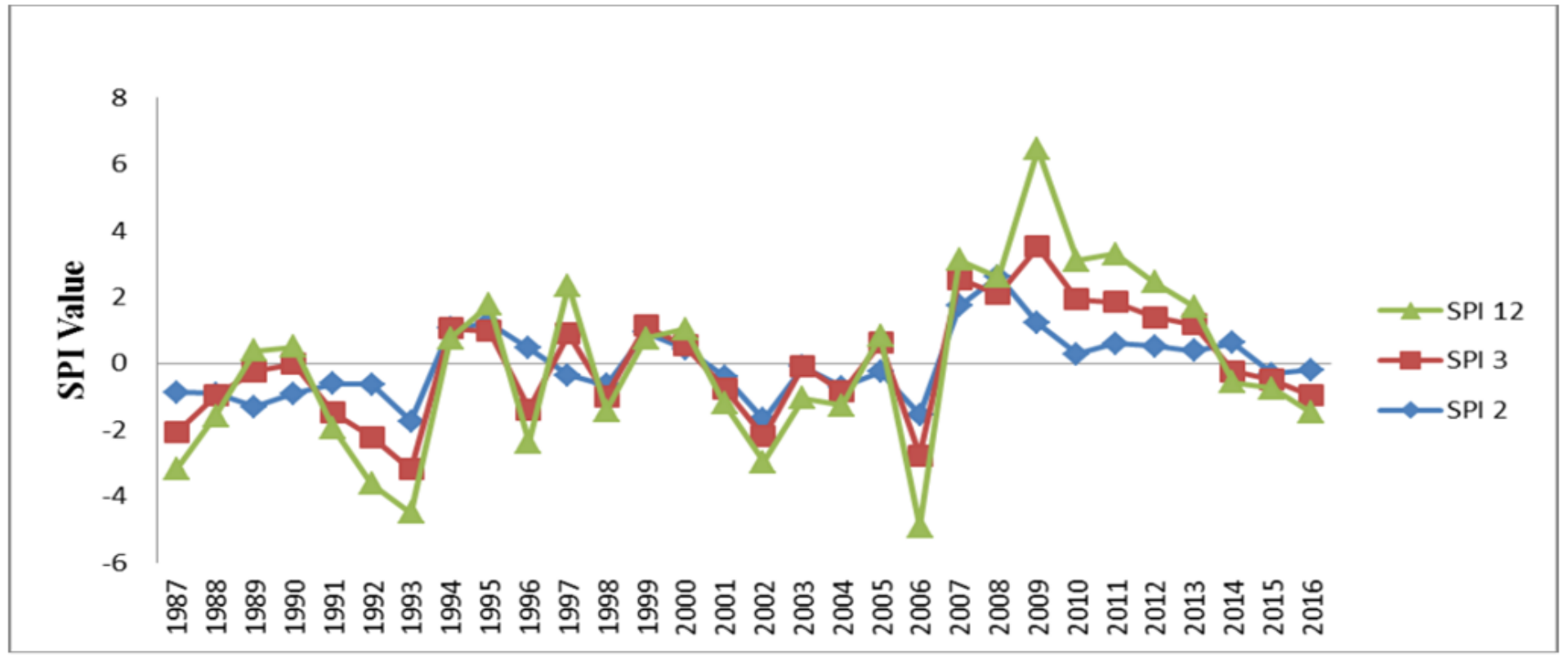

Figure 8

Trends of SPI value (2, 3 and 12 month) at Wadla station 